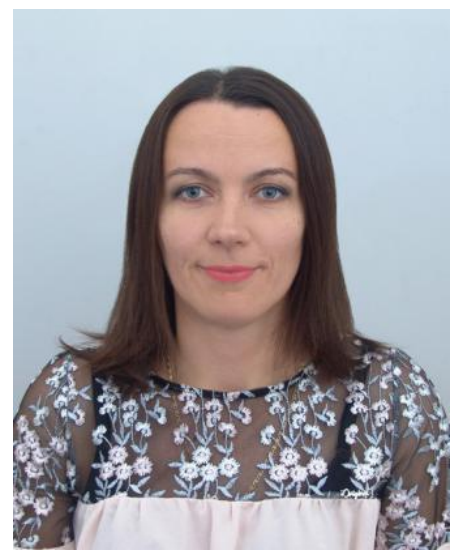

\begin{abstract}
Оксана Галан,
аспірант,

Кременецька обласна гуманітарно-педагогічна академія імені Тараса Шевченка (м.Кременець, Україна)
\end{abstract}

\author{
Oksana Halan, \\ Postgraduate student, \\ Taras Shevchenko Regional Humanitarian \\ and Pedagogical Academy (Kremenets, \\ Ukraine)ga_csa@ukr.net
}

\title{
ТЕОРЕТИЧНІ АСПЕКТИ ГОТОВНОСТІ МАЙБУТНІХ СОЦІАЛЬНИХ ПРАЦІВНИКІВ ДО ПРОФЕСІЙНОЇ ДІЯЛЬНОСТІ В УМОВАХ ВИЩОГО ЗАКЛАДУ ОСВІТИ
}

Анотація. Сучасний стан розвитку суспільства характеризується низкою негативних тенденцій, пов'язаних із загостренням соціально-економічних, соціально-педагогічних проблем та, як наслідок, у його житті спостерігається соціальна і психологічна дезадаптація. У таких умовах виникає необхідність підготовки соціальних працівників, здатних сприяти розвитку освітнього простору, інтеграції соціальних інститутів та гармонізації взаємовідносин людей. Відтак, потреба в утворенні нової генерації фахівців із соціальної роботи є пріоритетним напрямком в освітньому процесі вищих закладів освіти та знаходить відображення у Національній стратегії розвитку освіти в Україні на період до 2021 року та Законі України «Про освіту».

Успішність діяльності майбутнього соціального працівника пов'язана зі сформованістю в нього позитивної мотивації до особистісного розвитку та ціннісного ставлення до соціальної роботи. 3 цією метою у статті проаналізовано зміст та структуру готовності майбутніх фахівців соціальної сфери до професійної діяльності; охарактеризовано мотиваційноціннісний, інформаційно-когнітивний, організаційно-діяльнісний, особистісно-рефлексивний компоненти; проведено анкетування та дискусії зі студентами щодо означеної проблематики. Доведено, що мотиваційно-ціннісний компонент готовності майбутніх соціальних працівників до професійної діяльності $€$ смислоутворювальною складовою, оскільки передбачає формування стійкого прагнення студента до оволодіння знаннями, вміннями та навичками, усвідомлення практичної значущості соціальної роботи.

Ключові слова: майбутній соціальний працівник, готовність до професійної діяльності, психологічна готовність, практична готовність, мотиваційно-ціннісний компонент, інформаційно-когнітивний компонент, організаційно-діяльнісний компонент, особистісно-рефлексивний компонент.

\section{THEORETICAL ASPECTS OF FUTURE SOCIAL WORKERS' READINESS FOR PROFESSIONAL ACTIVITY IN HIGHER EDUCATION INSTITUTIONS}

Abstract. Current state of society development has been characterized by a number of negative trends associated with the aggravation of socio-economic, socio-pedagogical problems and, as a result, social and psychological disadaptation has been observed in its life. In such conditions, It is necessary to qualify social workers who can contribute to the development of the educational space, the integration of social institutions and the harmonization of people's relationships. Consequently, the need for a new generation of social work specialists has been a priority in the educational process of higher educational institutions and has been reflected in the National Strategy for the Development of Education in Ukraine until 2021 and in the Law of Ukraine "On Education".

The success of the future social worker has been observed due to the formation of his positive motivation for personal development and value attitude to social work. Therefore, the author has analyzed the content and structure of readiness of the future specialists in social sphere for their professional activity; characterized motivational-value, informational-cognitive, organizational-activity, personal-reflexive components; conducted Questionnaires and discussions with students on the identified issues. It has been proven that the motivational-value component of the readiness of future social workers for professional activity is a sensory component, since it involves the formation of a steady aspiration of the student to master the knowledge, skills and abilities and to acquire awareness of practical significance of social work.

Keywords: future social worker, readiness for professional activity, psychological readiness, practical readiness, motivationalvalue component, informational-cognitive component, organizational-activity component, personal-reflexive component.

\section{ВСТУП}

Постановка проблеми. В умовах сьогодення спостерігається підвищена увага наукової спільноти до належної підготовки майбутнього соціального працівника, оскільки вона є важливою передумовою цілеспрямованості і сприяє успіхам у його діяльності. Високий рівень їі сформованості допомагає майбутнім фахівцям кваліфіковано 
виконувати свої професійні обов'язки, обґрунтовано застосовувати знання, використовувати досвід, перебудовувати професійні дії у відповідності з життєвими ситуаціями. Її можна трактувати і як результат, і як мету професійної підготовки.

Аналіз останніх досліджень і публікацій. У монографіях, дисертаційних дослідженнях, наукових працях значною мірою висвітлено: основний зміст і розроблено основні напрями соціальної роботи в Україні (В. Бех, А. Капська, І. Лернер, М. Лукашевич, І. Мигович, О. Песоцька, В. Поліщук, Т. Семигіна),обґрунтовано природу дослідницьких процесів, необхідних для оптимального вибору методик навчання соціальних працівників (В. Семиченко, С. Харченко), виявлено окремі компоненти соціально-педагогічної діяльності у соціальній сфрері (Л. Міщик, Н. Кузьміна, О. Пономаренко), виокремлено готовність до розв'язання соціальних завдань у процесі навчання ( Н. Абашкіна, Г. Бурлака, І. Грига, С. Косянчук), розроблено і впроваджено у практику методики роботи з різними категоріями населення і в різних соціумах (О. Вакуленко, О. Карпухін, А. Капська, І. Трубавіна), окреслено деякі аспекти професійної підготовки соціального працівника (Л. Долинська, Д. Годлевська, В. Нор, В. Орленко, О. Шевчук, К. Якубенко).

Водночас, поглиблений аналіз наукових досліджень та емпіричних матеріалів дозволяє стверджувати необхідність розробки сучасного теоретико-методичного забезпечення готовності майбутніх соціальних працівників до професійної діяльності відповідно до вимог особистісно зорієнтованої освітньої парадигми в умовах вищих закладів освіти.

META I ЗАВДАННЯ ДОСЛІДЖЕННЯ. Мета статті - здійснити теоретичний аналіз змісту і структури готовності майбутніх соціальних працівників до професійної діяльності та висвітлити результати дослідження, спрямованого на формування мотиваційно-ціннісного компонента.

Завдання дослідження: розкрити вплив смислоутворювальної складової мотиваційно-ціннісного компонента на формування готовності майбутніх соціальних працівників до професійної діяльності; визначити рівень сформованості означеного компонента, використовуючи анкетування та дискусії зі студентами першого курсу спеціальності «Соціальна робота» Кременецької обласної гуманітарно-педагогічної академії ім. Тараса Шевченка.

\section{МЕТОДИ ДОСЛІДЖЕННЯ:}

- теоретичний аналіз наукової літератури з метою з'ясування ґрунтовних розробок досліджуваної проблеми;

- анкетування «Самооцінка готовності майбутніх соціальних працівників до професійної діяльності» 3 метою визначення рівня сформованості мотиваційно-ціннісного компонента готовності майбутніх соціальних працівників до професійної діяльності;

- дискусії на тему «Значущість соціальної роботи у власному професійному становленні» 3 метою формування мотиваційно-ціннісного компонента та покращення попередніх показників; кількісне та якісне опрацювання даних анкетування (\%).

\section{РЕЗУЛЬТАТИ ДОСЛІДЖЕННЯ}

Дослідження проблеми формування готовності майбутніх соціальних працівників до професійної діяльності, обґрунтування її наукових засад передбачає вивчення і аналіз стану в сучасній теорії та практиці, а також з'ясування сутнісного змісту й компонентного складу.

Варто зазначити, що необхідність поглибленого вивчення сутності поняття «готовність» викликана потребою пізнання науковцями рівня можливостей майбутнього фахівця у ефективному здійсненні професійної діяльності.

Відтак, вчена Т. Ковалькова, опираючись на дослідження науковців, стверджує, що у педагогічному аспекті готовність розглядається як багатокомпонентна система (О. Мороз, В. Сластьонін), а також як комплекс властивостей і якостей особистості (В. Крутецький) [8, с. 20].

Цей термін дослідники трактують неоднозначно, розглядаючи його з різних наукових позицій та підходів. Зокрема, вчені М. Дяченко та Л. Кандибович розуміють готовність як цілеспрямований прояв особистості, що містить у собі її переконання, погляди, мотиви, почуття, вольові та інтелектуальні якості, знання, уміння, навички, настанову до певної поведінки [1, с. 335 - 337].

В основу означеного поняття науковці включають психологічну складову. Вона являє собою особливий психічний стан, що активізує мотиваційні, пізнавальні, емоційні і вольові якості особистості до виконання певної діяльності.

На сучасному етапі розвитку освіти дослідники вважають, що готовність є результатом і показником якості підготовки і реалізується та перевіряється у процесі виконання професійних обов'язків. Учені визначають її як наявність здібностей особистості та пояснюють готовність як основну умову успішного виконання будь-якої діяльності. Тобто науковці стверджують, що вона містить практичну складову, що включає здатність особистості до здійснення діяльності на основі фахових знань та умінь.

Вчена О. Затворнюк підкреслює, що ядро поняття «готовність» включає в себе як психологічну готовність, яка є базою та стійкою платформою діяльності, так і практичну (професійну) готовність для застосування усіх знань і умінь $[6$, c. 38].

Опираючись на наукові дослідження проблеми, слід зауважити, що пріоритетне місце у формуванні готовності до професійної діяльності займає психологічна готовність. Вона виражається в єдності професійно важливих рис та спрямованості студента на майбутню соціальну роботу. Науковець О. Файчук стверджує, що саме психологічна готовність допомагає майбутньому соціальному працівнику успішно виконувати свої обов'язки, правильно використовувати знання, досвід, зберігати самоконтроль і перебудовуватися залежно від появи непередбачуваних ситуацій, сприяє швидкій та успішній адаптації до умов праці й постійного професійного вдосконалення [11, с. 28]. 
Вчена Г. Богатирьова доводить, що найбільш значущим є соціально-психологічний аспект готовності, зокрема, його комунікативно-психологічна складова. В її основу входить сфрормованість комунікативних умінь та навичок як елементів емоційної інтелігентності майбутнього фахівця [2, с. 69].

Науковець І. Гриценок, беручи до уваги дослідження І. Прокопенко, вважає, що психологічна готовність - це особистісне утворення, яке характеризується усвідомленням індивіда можливості реалізації власних здібностей в умовах професійної діяльності, наміром здійснення професійної кар'єри в єдності компонентів: мотиваційноціннісного (ціннісне ставлення до професії, інтерес до неї, потреба в кар'єрних досягненнях, ціннісні орієнтації), оцінювально-орієнтаційного (адекватна самооцінка, впевненість у собі), емоційно-вольового (емоційна стійкість, самоконтроль, цілеспрямованість) [3, с. 83].

Такий підхід вважаємо актуальним, оскільки для соціальних працівників надзвичайно важливо мати позитивну психологічну налаштованість, емоційну стабільність, сформовані емоційно-ціннісні детермінанти поведінки у професійних ситуаціях.

Більшість дослідників впевнені, що практична (професійна) готовність - це активний діяльнісний стан особистості, що включає систему інтегрованих властивостей: особистісно-мотиваційного ствердження, налаштованості на працю, уміння перемагати труднощі, бажання досягти успіху і уміння долати перешкоди.

Так, вчена К. Дурай-Новакова пропонує розглядати професійну готовність до педагогічної діяльності «як цілісне вираження всіх підструктур особистості, зорієнтованих на повне й успішне виконання різноманітних функцій учителя. Професійна готовність до педагогічної діяльності - складне структурне утворення, центральним ядром якого $є$ позитивні установки, мотиви й освоєні цінності вчительської професії. У цю готовність входять також професійно важливі риси характеру, педагогічні здібності, сукупність професійно-педагогічних знань, навичок, умінь, певний досвід їхнього застосування на практиці. Професійна готовність знаходиться в єдності зі спрямованістю на професійну діяльність і стійкими установками на працю» [10, с. 218].

Варто зазначити, що під час формування готовності майбутнього соціального працівника до фахової діяльності вкрай важливо акцентувати увагу на особливих якостях та рисах особистості, які становлять основу успішного виконання професійних обов'язків. Зокрема, значної уваги вчені надають певним особливостям френомена готовності, які окреслились у розумінні його як цілісного стану підготовленості, що забезпечує професійну спрямованість та обґрунтовує необхідність виконання професійних завдань. 3 точки зору дослідниці О. Карпенко, готовність соціальних працівників до професійної діяльності полягає у системі компонентів, якостей особистості майбутнього спеціаліста-професіонала, які забезпечують виконання ним функцій, адекватних потребам певної виробничої діяльності. Домінантою готовності є професійна компетентність фрахівця [7, с. 21].

Вивчаючи та узагальнюючи теоретичний доробок науковців щодо готовності майбутніх соціальних працівників до професійної діяльності, слід підкреслити, що його основу становить інтеграційне особистісне утворення, яке характеризується мотиваційно-ціннісною орієнтацією на здійснення системи соціальних заходів, а також професійноорієнтованими знаннями, вміннями і навичками та особистісними якостями, спрямованими на ефективне виконання професійної діяльності.

На нашу думку, готовність майбутнього соціального працівника до професійної діяльності полягає у чіткій спрямованості студента на здійснення соціальної роботи та сформованості професійно важливих рис у поєднанні із фаховими знаннями, уміннями, навичками та розвиненим емоційним ставленням до роботи, яку йому належить виконувати.

Розуміння готовності майбутнього соціального працівника до професійної діяльності як комплексного поєднання цілого ряду особистісних рис, якостей, знань, умінь, здібностей ставить питання виявлення ії структури. Сучасні науковці мають різні погляди на виділення складових компонентів означеного поняття.

Науковець О. Карпенко у дослідженні професійної підготовки майбутніх соціальних працівників в умовах університетської освіти виділяє три блоки компонентів готовності: мотиваційно-ціннісний, особистісно-професійний, соціально-професійний [7, с. 34-35].

Вчена Н. Павлишина виділяє чотири компоненти готовності майбутніх соціальних працівників до професійної діяльності у закладах соціального обслуговування людей похилого віку: мотиваційний, когнітивний, операційний, особистісний[9,с 142-148].

Проаналізувавши різні структури готовності майбутніх соціальних працівників до професійної діяльності, ми дійшли висновку, що спільними є такі компоненти:

- мотиваційний (ставлення до діяльності, мотиви);

- змістовий (знання про предмет і способи діяльності);

- операційний (уміння та навички продуктивної діяльності).

Однак, враховуючи специфіку дослідних завдань, вчені вводять додаткові компоненти у структуру готовності, що зумовлено особливостями фахової підготовки соціальних працівників. Водночас, дослідники акцентують увагу на повноцінному розвитку всіх структурних компонентів, оскільки вони є взаємодоповнюючими та взаємопов'язаними.

Беручи за основу проведений теоретичний аналіз наукової літератури, ми виділили наступні компоненти готовності, які, на нашу думку, є основними і значущими для нашого дослідження:

- мотиваційно-ціннісний (позитивне ставлення до професійної діяльності);

- інформаційно-когнітивний (система необхідних знань та пізнавальний інтерес до соціальної роботи);

- організаційно-діяльнісний (уміння та навички необхідні для професійної діяльності);

- особистісно-рефолексивний (сформованість якостей, здібностей та здатностей до фахової роботи). 
Далі розкриємо зміст структурних компонентів фрормування готовності майбутніх соціальних працівників до професійної діяльності.

Мотиваційно-ціннісний компонент виокремлюється практично усіма дослідниками. Припускаємо, що він $€$ смислоутворювальною складовою, оскільки передбачає формування стійкого прагнення майбутнього соціального працівника до особистісного розвитку, усвідомлення цінності та значущості соціальної роботи.

Важливою складовою цього компонента, як стверджують науковці О. Заїка та М. Чайковський, є також психологічні якості особистості майбутнього фрахівця соціальної сфери, які допоможуть йому здійснювати професійну діяльність. До них належать дві групи якостей: загальнолюдські (людяність, доброта, терпимість, гуманність, порядність, відповідальність, справедливість, емоційна щирість, позитивна «я-концепція») та професійні (загальна ерудиція, широкий культурний кругозір, наукова захопленість, любов до своєї роботи, потреба в самореалізації шляхом професійної діяльності, реалістичний і цілеспрямований підхід до життя, прагнення до самоосвіти та самовдосконалення, самостійність, активність) [4, с 96].

У нашому розумінні цей компонент відображає стійке позитивне ставлення до професійної діяльності, оскільки майбутні фрахівці мають чітко усвідомлювати, чому, для чого і що саме їм доведеться вивчити та засвоїти.

У процесі формування мотиваційно-ціннісного компонента передбачено ознайомлення 3 педагогічно ефективними світоглядними установками, які містять позитивно й емоційно забарвлені відомості, необхідні студентам для усвідомлення значущості соціальної роботи у власному професійному становленні.

У контексті дослідження припускаємо, що у процесі вивчення фахових дисциплін важливе є формування таких видів мотивації, які сприятимуть формуванню готовності майбутніх соціальних працівників допрофесійної діяльності, зокрема:

1) діяльнісно-мотиваційної, що виникає на основі потреби у здійсненні соціальної роботи;

2) пізнавальної, яка заснована на прагненні студентів до пізнання соціальних явищ, удосконалення професійної компетентності.

Критерієм сформованості мотиваційно-ціннісного компоненту визначено усвідомленість студентами вибору професії соціального працівника та значущості в ній соціальної роботи, а показниками є:

1) стійка мотивація до професійної діяльності;

2) потреба ефективно використовувати набутий теоретико-практичний досвід соціальної роботи;

3) особистісний сенс отримання фахових знань для успішної взаємодії із соціальними категоріями. Наступним

компонентом, який ми виділяємо в структурі готовності майбутнього соціального працівника $є$

інформаційно-когнітивний, який передбачає наявність системи теоретичних знань, необхідних для ефективної професійної діяльності, формує у свідомості майбутніх фахівців базові когнітивні структури, що забезпечують сприйняття i розуміння особливостей соціальної роботи. Формування міцних глибоких знань і здатності застосовувати їх на практиці - одна із найважливіших складових освітнього процесу підготовки майбутніх соціальних працівників. Вона дозволяє бачити, виділяти й ефективно вирішувати професійні проблеми і завдання, які можуть з'явитися під час виконання професійної діяльності. До змісту інформаційно-когнітивного компонента також належить професійне мислення, спрямування уваги, сприймання, пам'ять, дії та операції, необхідні для успішного здійснення професійної діяльності соціального працівника.

Далі у структурі ми виокремлюємо організаційно-діяльнісний компонент, який включає в себе перелік професійно важливих вмінь, що, в свою чергу, характеризує готовність до виконання професійних завдань. Він об'єднує в собі способи та прийоми соціально-педагогічної діяльності, здатність до виконання виробничих функцій. Показниками організаційно-діяльнісного компонента визначено професійні вміння, пов'язані з виконанням завдань саме у сфері освіти та виховання, які надалі він зможе удосконалювати у фаховій діяльності.

Особистісно-рефлексивний компонент готовності дозволяє майбутнім соціальним працівникам усвідомлено підійти до професійної діяльності, зрозуміти і вибрати для себе найпродуктивніші напрями роботи, а також передбачає наявність у студентів здатності оцінювати адекватність власних дій та форм поведінки в значущих для них ситуаціях, що здійснюється за допомогою оцінки власної готовності до професійної діяльності.

Академік І. Зязюн зазначав, що здатність особистості до продуктивного самовираження істотно визначається іiї рефлексуванням, особливо в реалізації функції проблематизації, самооб'єктивації, виявлення особистих смислів, побудови образу «Я-концепції» і наголошував при цьому на необхідності ставити і вирішувати завдання управління рефрлексією, а отже - виробляти методику такого управління [5, с.38-40].

За допомогою рефлексії як процесу самопізнання суб'єктом внутрішніх властивостей і станів, здійснюється розвиток самосвідомості. На відміну від свідомості, це не лише пізнання себе, орієнтування у власній особистості, але й певне ставлення до себе, здатне проявлятися у самооцінці.

3 метою визначення впливу мотиваційно-ціннісного компонента на формування готовності майбутніх соціальних працівників до професійної діяльності ми провели констатувальне дослідження (анкетування «Самооцінка готовності майбутніх соціальних працівників до професійної діяльності» студентів першого курсу спеціальності «Соціальна робота» Кременецької обласної гуманітарно-педагогічної академії ім. Тараса Шевченка).

Анкета містила наступні питання:

1. Чи впевнені Ви у суспільній значущості професійної діяльності соціального працівника?

20,2,\% опитаних відповіли, що усвідомлюють важливість соціальної роботи, 60,3\% - не надають великого значення професійній діяльності соціального працівника, 19,5\% респондентів не розуміють значимості фрахової роботи. Переважна більшість опитаних студентів не впевнені у значенні професійної діяльності соціального працівника. 
2. Чи маєте Ви бажання займатись соціальною роботою?

38,1\% респондентів підтвердили зацікавленість роботою соціального працівника, 42,5\% опитаних не мають стійкого інтересу займатись професійною діяльністю, 19,4\% не виявили бажання працювати у соціальній сфері.

3. Чи є для Вас актуальною активна моральна позиція у вирішенні соціальних проблем?

Відповіді студентів свідчать про те, що20,5\% опитаних розуміють необхідність опори на моральні цінності у професійній діяльності; 59,2\% -розуміють частково; 20,3\% - не розуміють.

4. Чи готові Ви до нестандартного, творчого вирішення професійних проблем?

14,9\% студентів вважають актуальним такий підхід,68,3\% студентів вважають недоцільним використання нестандарних підходів у розв'язанні соціальних труднощів, 16,8\% респондентів відповіли, що не впевнені у необхідності нестандартного підходу у вирішенні соціальної проблеми.

5. Чи вважаєте Ви, що спрямованість на позитивний результат є обов'язковим при здійсненні професійної діяльності?

$32,0 \%$ респондентів надали ствердну відповідь, 43\% респондентів надали негативну відповідь, $25 \%$ не знають, чи це обов'язково.

6. Чи погоджуєтесь Ви з тим, що майбутньому соціальному працівнику необхідно постійно розвиватись та самовдосконалюватись?

«Так» відповіли 28,2\% респондентів, «Ні» - 42,3\% респондентів, «Не знаю» - 29,5\%.

Аналіз отриманих на цьому етапі результатів дав можливість розподілити студентів за рівнем вираженості у них мотиваційно-ціннісного компонента досліджуваної готовності. У цілому високий рівень зафіксовано у 25,65\%досліджуваних, середній - у 52,60\%, низький - у 21,75\%.

Метою формувальної роботи ми вбачали розвиток у майбутніх соціальних працівників потреби і здатності до професійної діяльності. Відповідно проведені дискусії на різну тематику, зокрема - «Значущість соціальної роботи у власному професійному становленні». Під час складання сценарію дискусій ми допускали, що їх педагогічна ефективність підтвердиться, якщо вони будуть містити світоглядні установки, необхідні студентам для усвідомлення значущості соціальної роботи у власному професійному становленні.

У процесі дослідження завдань підвищення рівня мотиваційно-ціннісного компонента готовності майбутніх соціальних працівників до професійної діяльності зумовлювалось результатами анкетування.

3 метою формування стійкого прагнення майбутнього соціального працівника до особистісного розвитку, усвідомлення ним цінності та практичного значення професійної діяльності, для проведення дискусії ми підготували педагогічні ситуації.

У ході дискусій важливою була думка викладача, яка висловлена наприкінці, коли студенти якомога більш розгорнуто обґрунтували свої погляди. У процесі дискусії педагог не приймав жодної сторони, намагаючись активізувати участь у ній максимальної кількості студентів.

Для визначення ефективності здійсненого дослідження провели повторне анкетування, результати якого показали збільшення рівня сформованості мотиваційно-ціннісного компонента, а саме: високий рівень зафіксовано у $30,65 \%$ досліджуваних, середній - у 62,60\%, низький - у 6,75\%.

Порівняльні результати рівнів сформованості мотиваційно-ціннісного компонента представлено на рис.1.

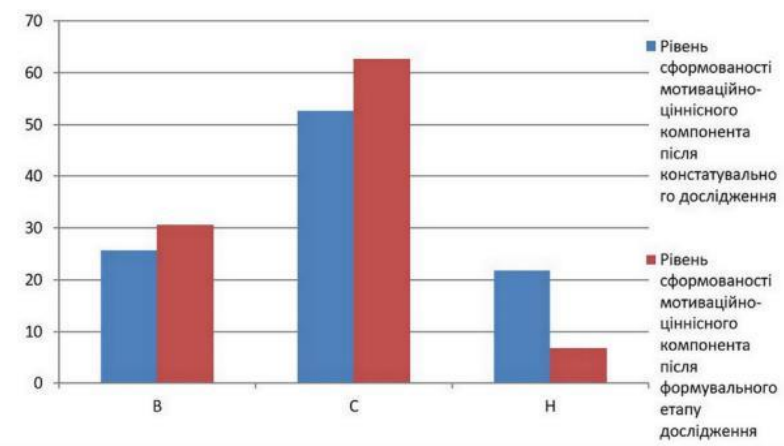

Puc.1. Зміна рівнів сорормованості мотиваційно-ціннісного компонента в групі студентів I курсу спеціальності «Соціальна робота». Умовні позначення: $B$ - високий рівень; $C$ - середній рівень; Н-низький рівень.

Під час формування мотиваційно-ціннісного компонента ми прагнули забезпечити усвідомлення студентами смислоутворювальної складової готовності майбутніх соціальних працівників до професійної діяльності. На цій основі розкривалася діяльнісно-мотиваційна та пізнавальна мотивація, яка виникає у процесі вивчення фахових дисциплін. У нашому дослідженні її фрормування забезпечувалось організацією дискусій, метою яких було висловлення різних точок зору та спільний аналіз ситуацій вищеозначеної проблеми. Зіткнення різноспрямованих позицій студентів викликав у них жвавий інтерес, активізував рефлексивні механізми мислення, необхідні для обґрунтування своєї позиції, пошуку аргументів, зіставлення різних смислових позицій у вирішенні проблеми.

Водночас ствердження науковців О. Заїки та М. Чайковського щодо розвитку психологічних якостей особистості майбутнього соціального працівника як важливої складової мотиваційно-ціннісного компонента 
готовності до професійної діяльності не викликає сумніву, так як загальнолюдські та професійні якості сприятимуть ефективній соціальній роботі.

\section{ВИСНОВКИ ТА ПЕРСПЕКТИВИ ПОДАЛЬШИХ ДОСЛІДЖЕНЬ}

Таким чином, у результаті дослідження встановлено, що стійка мотивація майбутнього соціального працівника до профресійної діяльності, потреба ефективно використовувати набутий теоретико-практичний досвід соціальної роботи та особистісний сенс отримання фахових знань - запорука високого рівня сформованості мотиваційно-ціннісного компонента готовності до професійної діяльності майбутніх соціальних працівників.

\section{СПИСОК ВИКОРИСТАНИХ ДЖЕРЕЛ}

[1] Дьяченко М И. Психологические проблемы готовности к деятельности. Минск, 1976. 175 с.

[2] Богатирьова Г. Комунікативно-психологічна складова готовності фахівців з туризму до екскурсійної діяльності. Науковий вісник інституту професійно-технічної освіти НАПН України.2018. №15. С. 67-73.

[3] Гриценок І. Формування психологічної готовності учнів закладів професійної (професійно-технічної) освіти до вибору й реалізації професійної кар'єри. Науковий вісник інституту професійно-технічної освіти НАПН України.2018. №15. С. 81-87.

[4] Заїка О. П., Чайковський М. Є. Основні проблеми професійної підготовки майбутніх соціальних працівників до діяльності в полікультурному середовищі. Збірник наукових праць Хмельницького інституту соціальних технологій Університету «Укра-їна». 2013. №1(7). С. 93-96.

[5] Зязюн І. А. Психолого-педагогічні проблеми професійної освіти. Наук.-метод. збірник. Київ: ICДО,1994.С. 38-40.

[6] Затворнюк О. М. Формування готовності у майбутніх психологів до професійного самовдосконалення: дис. ... канд. пед. наук: 13.00.04 / Нац. пед. ун-т ім. М. П. Драгоманова. Київ, 2016.

[7] Карпенко О. Г. Професійна підготовка майбутніх соціальних працівників в умовах університетської освіти: автореф. дис. ... д-ра пед. наук: Київ, 2008. 46с.

[8] Ковалькова Т. О. Формування готовності майбутніх психологів до професійної діяльності в авіаційній галузі у процесі фахо-вої підготовки: дис. ... канд. пед. наук: 13.00.04 / Нац. авіаційний ун-т. Київ, 2016.

[9] Павлишина Н. Б. Структура готовності майбутніх соціальних працівників до професійної діяльності у закладах соціального обслуговування людей похилого віку. Освітологічний дискурс.2014. №2(6). С. 142-148.

[10]Татауров В. П. Особливості формування готовності майбутніх педагогів до використання інформаційно-комунікаційних технологій. Збірник наукових праць:Розділ III. Методика викладання природничих дисциплін. 2012. Випуск 10. С. 215-220.

[11] Файчук О. Л. Готовність майбутніх соціальних працівників до роботи з бездомними громадянами. Наукові праці:Педагогіка. 2016. Випуск 257. Том 269. С. 28-32.

\section{REFERENCES (TRANSLATED AND TRANSLITERATED)}

[1] Djjachenko M Y. Psykhologhycheskye problemy ghotovnosty k dejateljnosty (Psychological issues of readiness for activity). Mynsk, 1976. 175 s. (in Russian)

[2] Boghatyrjova Gh. Komunikatyvno-psykhologhichna skladova ghotovnosti fakhivciv z turyzmu do ekskursijnoji dijaljnosti (Communicative-psychological component of the readiness of tourism professionals to excursion activities). Naukovyj visnyk instytutu profesijno-tekhnichnoji osvity NAPN Ukrajiny.2018. № 15. S. 67-73. (in Ukrainian)

[3] Ghrycenok I. Formuvannja psykhologhichnoji ghotovnosti uchniv zakladiv profesijnoji (profesijno-tekhnichnoji) osvity do vyboru j realizaciji profesijnoji kar'jery (Formation of psychological readiness of students of vocational (vocational) education institutions for the selection and implementation of professional careers). Naukovyj visnyk instytutu profesijno-tekhnichnoji osvity NAPN Ukrajiny.2018. № 15. S. 81-87. (in Ukrainian)

[4] Zajika O. P., Chajkovsjkyj M. Je. Osnovni problemy profesijnoji pidghotovky majbutnikh socialjnykh pracivnykiv do dijaljnosti v polikuljturnomu seredovyshhi (The main problems of the training of future social workers to work in the multicultural environment). Zbirnyk naukovykh pracj Khmeljnycjkogho instytutu socialjnykh tekhnologhij Universytetu «Ukrajina».2013.№ 1(7). S. 93-96. (in Ukrainian)

[5] Zjazjun I. A. Psykhologho-pedaghoghichni problemy profesijnoji osvity (Psychological-pedagogical problems of vocational education). Nauk.-metod. zbirnyk. Kyjiv: ISDO,1994.S. 38-40. (in Ukrainian)

[6] Zatvornjuk O. M. Formuvannja ghotovnosti u majbutnikh psykhologhiv do profesijnogho samovdoskonalennja (Formation of preparedness for future psychologists to professional self-improvement): dys. ... kand. ped. nauk: 13.00 .04 / Nac. ped. un-t im. M. P. Draghomanova. Kyjiv, 2016. (in Ukrainian)

[7] Karpenko O. Gh. Profesijna pidghotovka majbutnikh socialjnykh pracivnykiv v umovakh universytetsjkoji osvity (Professional training of future social workers in university education): avtoref. dys. ... d-ra ped. nauk: Kyjiv, 2008. 46 s. (in Ukrainian)

[8] Kovaljkova T. O. Formuvannja ghotovnosti majbutnikh psykhologhiv do profesijnoji dijaljnosti v aviacijnij ghaluzi u procesi fakhovoji pidghotovky (Formation of readiness of future psychologists for professional activity in the aviation industry in the process of professional training): dys. ... kand. ped. nauk: 13.00.04 / Nac. aviacijnyj un-t. Kyjiv, 2016. (in Ukrainian)

[9] Pavlyshyna N. B. Struktura ghotovnosti majbutnikh socialjnykh pracivnykiv do profesijnoji dijaljnosti u zakladakh socialjnogho obslughovuvannja ljudej pokhylogho viku (The structure of the readiness of future social workers for professional activities in social service facilities for the elderly). Osvitologhichnyj dyskurs.2014. № 2 (6). S. 142-148. (in Ukrainian)

[10] Tataurov V. P. Osoblyvosti formuvannja ghotovnosti majbutnikh pedaghoghiv do vykorystannja informacijno-komunikacijnykh tekhnologhij (Features of forming the readiness of future teachers to use information and communication technologies). Zbirnyk naukovykh pracj:Rozdil III. Metodyka vykladannja pryrodnychykh dyscyplin. 2012. Vypusk 10. S. 215-220. (in Ukrainian)

[11] Fajchuk O. L. Ghotovnistj majbutnikh socialjnykh pracivnykiv do roboty z bezdomnymy ghromadjanamy (Readiness of future social workers to work with homeless people). Naukovi praci: Pedaghoghika. 2016. Vypusk 257. Tom 269. S. 28-32. (in Ukrainian) 